\title{
Etem Yeşilyurt
}

Mevlana University, Konya-Turkey. eyesilyurt@mevlana.edu.tr

\section{YAPILANDIRMACI ÖĞRENME KURAMINA İLIŞKİN BİLIŞSEL FARKINDALIK ÖLÇEĞİ GELİ̧̧TIRME ÇALIŞMASI: BIR ÖLÇEK REVİZYONU}

\section{ÖZET}

Bu çalışmada 'Yapılandırmacı öğrenme konusunda öğretmen adaylarının yeterliği ölçeği: Geçerlik ve güvenirlik çalışması' yeniden gözden geçirilmiştir. Çalışmanın amacı, gözden geçirilen ölçekten elde edilen 'Yapılandırmacı öğrenme kuramına ilişkin bilişsel farkındalık ölçeğinin geçerlik ve güvenirliğini test etmektir. Çalışma grubu 425 öğretmen adayından oluşmaktadır. Ölçeğin görünüş ve kapsam geçerliği uzman görüşüyle, yapı geçerliği ise açımlayıcı ve doğrulayıcı faktör analizleriyle yapılmıştır. Ölçeğin güvenirliği Cronbach Alpha, eşdeğer form, tekrar test ve iki yarı test güvenirliği test edilmiştir. Sonuç olarak, geliştirilen bu ölçme aracının, öğretmen adaylarının ve öğretmenlerin yapılandırmacı öğrenme kuramına ilişkin bilişsel farkındalık düzeyinin belirlenmesinde kullanılabilecek geçerli ve güvenilir bir veri toplama aracı olduğu söylenebilir.

Anahtar Kelimeler: Yapılandırmacı Öğrenme Kuramı, Bilişsel Farkındalık, Ölçek Geliştirme, Ölçek Revizyonu, Öğretmen ve Öğretmen Adayı

\section{STUDY ON SCALE DEVELOPMENT METACOGNITION ABOUT CONSTRUCTIVIST LEARNING THEORY: REVISION OF A SCALE}

\section{ABSTRACT}

This study was aimed to test the validity and reliability of the 'scale of metacognition about constructivist learning theory' for this reason, 'development of the scale of teacher candidates' competency on constructivist learning: study of reliabllity and validity' was revised. The study group of the research consists of 425 pre-service teachers. Confirmatory and exploratory factor analyses were done for construct validity. Reliability of the scale was tested via Cronbach's Alpha, equivalent form, re-test and the two semi-test reliability. As a result, this scale is reliability and validity for the pre-service teachers and teachers for determining metacognition about constructivist learning theory.

Keywords: Constructivist Learning Theory, Metacognition, Scale Development, Scale Revision, Teacher and Teacher Candidate 


\section{GIRISS (INTRODUCTION)}

Bruner tarafından 1960'lı yılların başında sistematik bir şekilde eğitim gündemine getirilen yapılandırmacı kuramın felsefi kökeni iki bin yıl öncesine dayanmaktadır (Şimşek, 2004). Yapılandırmacılığı benimseyen ilk eğitimci 18. yüzyılda İtalya'da yaşayan Giambattista Vico'nun olduğu ileri sürülmektedir (Yaşar, 1998). Tarihsel süreç içerisinde ise bu kuramın önde gelen teorisyenleri Piaget, Bruner, Vygotsky ve Dewey'dir (Yanpar, 2001). Ancak bu kuramın geliştirilip tanımlanmasında Piaget'in (1973) çocuğun ruhsal gelişimine ilişkin görüşleri etkili olmuştur (Sert, 2008).

Davranış̧ılıktan farklı bir temele dayanan yapılandırmacı öğrenme kuramı (Fosnot ve Perry, 2005), insanın nasıl öğrendiğini ele almaktadır (Durmuş, 2001). Günümüzde bilginin nasıl yapılandırıldığına ve oluşturulduğuna ilişkin bir kurama dönüşen yapılandırmacılığın (Erdem ve Demirel, 2002) özünde, öğrenin bilgiyi yapılandırması ve uygulamaya koyması yer almaktadır (Perkins, 1999). Bu kuram bilgide öznelliğe, anlam oluşturmaya, öğrenci odaklılığına ve program esnekliğine vurgu yapmaktadır (Aydın, 2007). Yapılandırmacılık, bilgi ve öğrenmeye, bilgiyi temelden yapılandırmaya dayanan, öğrenenin bilgiyi nasıl öğrendiğine ilişkin olarak gelişen ve zaman içerisinde bunu nasıl yapılandırdığını göstermeye çalışan bir öğrenme kuramdır (Demirel, 2012). Yapılandırmacı öğrenme kuramına göre sorunlara yeni ve farklı çözümler bulmaları, diğer öğrenenler ya da uzmanlarla işbirliği yapmaları, düşüncelerini ve öne sürdükleri hipotezlerini denemeleri, düşünme şekillerini gözden geçirmeleri ve en iyi çözümü sunmaları için öğrenciler desteklenmelidir (Can, 2004).

Düşünürlerin felsefi görüşleri arasında tam bir özdeşlik mevcut olmadığı için, yapılandırmacılık tanımlarının tümüyle benzer olduğunu söylemek doğru olmamaktadır. Kavram olarak yapılandırmacılık, insanların nasıl öğrendiğini açıklamaya çalışan bir kuramın adı, felsefi bakımdan bilgi ve bilim ile ilgili bir kavramdır. Diğer bir deyişe yapılandırmacılık bilginin doğasını açıklamaya çalışmaktadır (Arslan, 2007). Bu noktada Açıkgöz (2007) yapılandırmacılığın bilgi, bilginin doğası ve yapılandırılması sürecinin nasıl bir süreç olduğu, bu sürecin nelerden etkilendiği gibi konularla ilgilendiğini ileri sürmektedir. Konuyla ilgili olarak Aydın (2006) ise ontolojik ve epistemolojik görüşlerinin uzantılarının yer aldığı bu tanımların bilişsel, toplumsal, radikal ve felsefi yapılandırmacılığa temel oluşturduğu gerçeğine dikkat çekmektedir. Bu bağlamda yapılandırmacılık; öğrenenin karşılaşılan bilgileri önceki bilgileriyle ilişkilendirerek öğrenmesi, bildiği konulara bağlı olarak öğrenenin yeni öğrenmeler oluşturması (Thomas ve Barbara, 2005), çevre koşulıarından bağımsız gerçekleşen anlamlandırma, bakış açısı kazanma ve bilgiyi yapılandırma süreci (Yurdakul, 2007) olarak tanımlanabilir.

Arslan (2007) yapılandırmacı öğrenme kuramında bilginin pasif olarak toplanmadığı, onun birey tarafından aktif olarak oluşturulduğu ileri sürmektedir. Ersoy'a (2005) göre ise yapılandırmacı öğrenme kuramına göre bireyler bilgiyi etkin olarak yapılandırır. Bireyin bilgiyi oluşturmasına, geliştirmesine, yorumlamasına ve yeniden yapılandırmasına yardımcı olan yapılandırmacı öğrenme kuramı (Laçin, 2008), bilginin transferini ve yeniden yapılandırılmasını gerektirmektedir (Perkins, 1999). Bu noktada Von Glasersfeld (2005) bilgiyi oluşturan kavramsal yapıların, onu kullanan bireylerin kendileri için yapmak zorunda olduğu yapılar olarak ele almakta ve bir bakıma bilgiyi oluşturan kavramların bireyselliğine işaret etmektedir. Öte yandan Sönmez (2011), gerçek ve insan değiştiğinden, kesin (mutlak) bilginin olmadığını ve hakikatin ölçüsü insan olduğundan bilginin göreceliliğine dikkat çekmektedir. 


\begin{abstract}
Yapılandırmacı öğrenme kuramı, öğrenciyi ve öğrencinin zihinsel gelişimini merkeze almaktadır (Güneş, 2007). Başka bir deyişle yapılandırmacılıkta, bireylerin yeni davranış ve düşüncelerinin önceden yapılandırılmış düşüncelerine ve ön bilgilerine dayandığı tezi vardır (Tsai, 2002). Bu noktada Bruner de (1966) öğrenmenin, yeni bilginin var olan yani eski bilgilere dayandırılarak yeni fikirler ve kavramların oluşturulduğu etkin bir süreç olduğunu vurgulamaktadır (Can, 2004). Bu bakımdan anlamlı bir öğrenme için öğrenci yeni bilgileri var olan zihinsel yapısı üzerine aktif bir biçimde yerleştirmelidir. Kavramsal bir değişmeyi içeren öğrenme öznel, durumsal, sosyal, duygusal, gelişimsel, sürekli ve öğrenci merkezlidir (Duman, 2004). Yapılandırmacı öğrenmeyi, Yurdakul (2007) ise, bilgiyi bireyin eylemleriyle ve bu eylemlerden edindiği deneyimlerle ilişkili bir süreç olarak ele almaktadır.
\end{abstract}

Yapılandırmacı öğrenme kuramı, öğrenci üzerinde odaklanır ve öğrencinin kendi kavramlarını ve problem çözümlerini inşa eder. Bu kuramda öğrencinin özerkliği ve müteşebbisliği kabul edilerek, onların yeni bilgileri daha önceki bilgiler üzerine inşa etmesine imkân tanınır. Yapılandırmacı öğrenme kuramına göre öğrenenler, bilgiyi olduğu gibi kabul etmezler, onu oluşturur ya da tekrar keşfederler (Perkins, 1999). Çünkü yapılandırmacı öğrenme; bilinçli, yaratıcı, araştıran, soruşturan, neyi, nerede ve niçin öğrendiğini bilen (Jonassen, Peck ve Wilsom, 1999), girişimci, kendini ifade edebilen, iletişim kurabilen, eleştirel gözle bakabilen, plan yapabilen, öğrendiklerini yaşamda kullanabilen öğrencilerin yetişmesini amaç edinmektedir (Marlowe ve Page, 1998). Kendi öğrenmelerinden sorumlu olan öğrenenler (Özden, 2003), içerik ve süreci aynı zamanda öğrenmektedir (Şaşan, 2002).

Brooks ve Brooks'a (1999) göre yapılandırmacı öğrenme kuramına göre öğretim sürecinde öğrenci özerk olmalı, sorgulamalı ve bireyler öğrenme sürecinde daha fazla sorumluluk almalıdır. Dolayısıyla, yapılandırmacı öğrenme ortamları, bireylerin çevreleriyle daha fazla etkileşimde bulunmalarına, zengin öğrenme yaşantıları geçirmelerine olanak sağlayacak biçimde düzenlenmelidir. Benzer bir görüşü diler getiren Yaşar (1998) eğitsel ortamların öğrenenlerin bilgilerini sınamalarına ve yanlışlarını düzeltmelerine yardımcı olacak şekilde düzenlenmesinin önemi vurgulamaktadır. Sınıfın fiziksel özellikleri ve öğretim süreci öğrenci merkezli, esnek olmalı (Ersoy, 2005), sınıf kalabalık olmamalı, öğrencilerin etkinliklerini karşılayıcı şekilde düzenlenmeli, öğretim teknolojileri ile desteklenmeli, düzen ve biçim değişikliği yapılabilecek şekilde esnek yapıda olmalıdır (Yapıcı, 2008). Çünkü yapılandırmacı öğrenme ortamı öğretmene daha zengin ve esnek bir sınıf ve ders ortamı sunmakta ve öğrenme-öğretme sürecinde oldukça zengin materyal çeşitliliği sağlamaktadır (Gömleksiz ve Elaldı, 2011). Dolayısıyla eğitim ortamlarında öğrenenleri aktif kılan öğretim ilke ve yönetmeleri kullanılmalıdır (Şaşan, 2002).

Yapılandırmacı öğrenmeye göre rehber konumda olan öğretmen öğrencileri soru sormaya, kendi fikirlerini formüle etmeye ve sonuçlar çıkarmaya teşvik edici olmalıdır (Bağcı, 2003). Bu noktada öğretmen "öğrenci nasıl öğrenmektedir?" sorusundan yola çıkarak eğitim durumlarını sorgulamalıdır (Mısır ve Çalışkan, 2007). Yapılandırmacı öğrenmeyi ilke edinen bir öğretmenin görevleri arasında yaratıcılık, eleştirel ve analitik düşünceyi merkeze alma, yaparak-yaşayarak öğrenmeyi sağlama ve öğretim yöntemi konusunda geniş bilgiye ve kullanım yeteneğine sahip olma vb. yer almaktadır (Aydın, 2007). Öte yandan Demirel (2012) bu kurama göre bir öğretmenin öğrenci ilgilerini merkeze alması, öğrenmenin ve öğrenmeyi değerlendirme sürecinin güç ve karmaşık bir çaba olduğunu göz önünde bulundurması gerekmektedir. 


\begin{abstract}
Yapılandırmacı öğrenme açısından öğretmenlerin görevleri arasında önemli bir yer tutan başka bir öğe ise değerlendirmedir. Değerlendirme, öğretimden ayrı değil, öğretimin içinde yer alan ve öğretime yön veren, devam eden bir süreç olarak görülmektedir. Yapılandırmacı öğrenme kuramında değerlendirme süreç sonunda yer almamakta, öğrenme ve program faaliyetlerinin nasıl devam edeceği hakkında bilgi vermektedir (Marlowe ve Page: 1998, Akt. Yurdakul, 2008). Öte yandan öğretmen öğrencinin akademik başarısını değerlendirirken öğrenenlerin hem sınavlardan aldıkları puanları hem de öğrenme sürecinde yapmış oldukları tüm etkinlikleri dikkate almalıdır (Kılıç, Karadeniz ve Karataş, 2003). Bu noktada Bednar ve diğerleri (1991, Akt. Gürol, 2002), yapılandırmacı öğrenmenin değerlendirilmesinde iki yöntemin izlenmesi gerektiğine işaret etmektedirler. Birinci yöntemde, bir içerik alanına yönelik öğrencilerin nasıl işlevde bulunduğu, ikinci yöntemde ise süreçler üzerindeki öğrenci yansıtmaları dikkate alınmaktadır.

öğrenme sürecinde aktif katılımcı konumda olan öğrencinin, yapılandırmacı öğrenme ve bilgi üretme sürecine de aktif katılımını sağlayan faktörlerden biri de öğrencinin bilişsel farkındalığıdır. Bir düşünme sistemi olan bilişsel farkındalık, öğrenmeyi öğrenme, dikkati odaklama, yapılacak işi adım adım planlama, öğrenme sürecinin her aşamasını değerlendirme, gerekli düzeltme ve düzenlemeyi yapma işidir (Paris ve Winograd, 1990, Akt. Demir ve Doğanay, 2009). Bilişsel farkındalık, bireyin kendi biliş sistemi, yapısı, çalışması hakkındaki bilgisidir. Diğer bir deyişle, bilişsel farkındalık bireyin kendi biliş yapısı ve öğrenme özelliklerinin farkında olmasıdır (Demir veDoğanay, 2009). Bilişsel farkındalık becerisine sahip olan birey görevin veya problemin ne olduğunu tanımlar, görevi yerine getirmek ve problemi çözmek için en uygun stratejiyi seçer, kaynakları zamanında bulur, önceki ilgili bilgiyi aktif hale getirir (İflazoğlu saban ve Saban, 2008).

Öte yandan bilişsel farkındalık becerilerine sahip olan bir birey öncelikle öğreneceği konuya motive olur, dikkatini yoğunlaştırır, tutum geliştirir, kendisi hakkındaki bilgisini ve kendi düşüncesini kontrol eder. Daha sonra ne bildiğini ve ne bilmesi gerektiğini değerlendirir, nerede olduğunu görür. Bunu takiben yapacağını planlar, planını değerlendirir, düzeltir ve tekrar dener. Son olarak da ne kadar öğrendiğinin, nasıl öğrendiğinin, hangi düşünme yollarını izlediğinin farkına varır, bunu geliştirir ve bu becerileri bir yaşam tarzı haline getirir (Gelen, 2004). Dolayısıyla yapılandırmacı öğrenme kuramı özelliklerinin ve niteliklerinin bilinirliği, tanınırlığı, anlaşılırlığı ve bu kuramın uygulamadaki başarı düzeyi konuyla ilgili geliştirilen ölçekler aracılığıyla ortaya konulabilir ve somutlaştırılabilir.
\end{abstract}

\title{
2. ÇALIŞMANIN ÖNEMI (RESEARCH SIGNIFICANCE)
}

Yapılandırmacı öğrenme ile ilgili az sayıda da olsa yerli ve yabancı alanyazında çeşitli ölçeklerin geliştirildiği görülmektedir. Taylor, Fraser ve Fisher (1997) ile Tenenbaum, Naidu, Jegede ve Austin (2001) tarafından geliştirilen ve aynı adları taşıyan "Yapılandırmacı Öğrenme Ortamı Ölçeği (Constructivist Learning Environment Survey CLES)" yapılandırmacı öğrenme kuramıyla ilgili olarak en çok kullanılan ölçeklerdir. Adı geçen ölçekler sırayla Küçüközer, Kırtak Ad, Ayverdi ve Eğdir (2012) ile Fer ve Cırık (2006) tarafından Türkçe'ye uyarlanmıştır. Hambleton ve Patsula (1999. Akt. Arkün ve Aşkar, 2010) ölçek uyarlamanın, ölçek geliştirmeye göre tercih edilmesinin her zaman doğru olmadığını vurgulamaktadır. Onlar, kültürler arası karşılaştırmaların söz konusu olmadığı durumlarda, 
yeni bir ölçek geliştirmenin hem daha kolay, hem de daha uygun olduğu düşüncesini taşımaktadır.

Bu bağlamda konuyla ilgili olarak birkaç ölçek geliştirilmiştir. Bay, Kaya ve Gündoğdu (2010) tarafından yapılandırmacı öğrenme ortamlarının demokratik olma durumlarını belirlemeye yönelik bir ölçme aracının geliştirilmesi amaçlanmış ve çalışma sonucunda "demokratik yapılandırmacı öğrenme ortamı ölçeği" geliştirilmiştir. Bu çalışmada genel olarak öğrenme ortamı üzerinde durulmuştur. Başka bir çalışmada ise Evrekli, İnel, Balım ve Kesercioğlu (2009) tarafından, öğretmenlerinin yapılandırmacı kuramdaki önemi üzerinde durulmuş ve fen öğretmenlerine yönelik yapılandırmacı yaklaşım tutum ölçeği geliştirilmiştir. Ölçek genel olarak tutum esaslı olup belli bir alandaki öğretmenlere hitap etmektedir. Öte yandan Arkün ve Aşkar (2010) tarafından yapılandırmacı öğrenme ortamlarını değerlendirmeye bir ölçek geliştirilmiştir. Bu ölçek ise temelde öğrenme ortamları üzerine odaklanmaktadır.

Yapılan ölçek geliştirme çalışmalarına genel olarak bakıldığında, geliştirilen ölçeklerin hem nicel olarak yetersiz hem de yapılandırmacı öğrenme kuramının belli boyutlarını ele aldığı görülmektedir. Alana katkı sağlayacağı düşüncesinden hareketle bu çalışmada 'yapılandırmacı öğrenme konusunda öğretmen adaylarının yeterliği ölçeği: geçerlik ve güvenirlik çalışması' (Yeşilyurt, 2012) yeniden gözden geçirilerek 'yapılandırmacı öğrenme kuramına ilişkin bilişsel farkındalık ölçeği'nin geçerlik ve güvenirliği test edilmiştir. Ölçeğin yeniden yapılandırılmasının ana nedenlerini; ölçeğin toplam varyansı açıklama yüzdesinin düşük olması (\%45,948), ölçeğin 'yeterlik' yerine 'bilişsel farkındalık' olarak yeniden adlandırılması, likert türü ifadelerin değiştirilmesi, birden fazla yöntem kullanılarak güvenirlik analizlerinin yapılması ile açımlayıcı faktör analizi sonucunda elde edilen yapının birinci ve ikinci düzey doğrulayıcı faktör analizi ile test edilmesi oluşturmaktadır.

\section{AMAÇ (PURPOSE)}

Çalışmanın amacı, bu makalenin yazarı tarafından geliştirilen, "yapılandırmacı öğrenme konusunda öğretmen adaylarının yeterliği ölçeği: geçerlik ve güvenirlik çalışmasının yeniden gözden geçirilerek elde edildiği "yapılandırmacı öğrenme kuramına ilişkin bilişsel farkındalık ölçeği"nin geçerlik ve güvenirliğini test ederek ölçeğin psikometrik özelliklerini incelemektir. Bu bağlamda, öğretmen adaylarının ve öğretmenlerin yapılandırmacı öğrenme kuramına ilişkin bilişsel farkındalık düzeyini belirlemede kullanılabilecek güvenilir, geçerli ve etkin kullanım özelliklerine sahip bir ölçek geliştirmeye çalışılmıştır.

\section{YÖNTEM (METHOD)}

\section{1. Çalışma Grubu (Study Group)}

Araştırmanın çalışma grubunu, 2012-2013 akademik yılı güz döneminde Mevlana Üniversitesi Eğitim Fakültesi'ndeki lisans programları ikinci ve üçüncü sınıf düzeyi ile aynı üniversitenin pedagojik formasyon bünyesinde öğrenimini sürdüren 425 öğretmen adayı oluşturmaktadır. Araştırmaya gönüllü olarak katılan ve çalışma grubunda yer alan öğretmen adaylarının demografik özelliklerine Tablo $1^{\prime}$ de yer verilmiştir. 
Yeşilyurt, $E$

NWSA-Education Sciences, 1C0588, 8, (2), 285-307.

Tablo 1. Çalışmaya katılan öğretmen adaylarının demografik özellikleri (Table 1. Demographic characteristics of pre-service teachers

participated in study)

\begin{tabular}{|c|c|c|c|}
\hline \multicolumn{4}{|c|}{ Demografik Özellikler } \\
\hline & Cinsiyet & $\mathrm{f}$ & $\frac{\circ}{0}$ \\
\hline 1 & Kadın & 315 & 74,1 \\
\hline 2 & Erkek & 110 & 25,9 \\
\hline & Toplam & 425 & 100.0 \\
\hline & Sınıf Düzeyi & f & $\frac{\circ}{0}$ \\
\hline 1 & Pedagojik formasyon & 105 & 24,7 \\
\hline 2 & İkinci Sınıf & 210 & 49,5 \\
\hline 3 & Üçüncü Sınıf & 110 & 25,8 \\
\hline & Toplam & 425 & 100.0 \\
\hline & Bölüm/Program Türü & f & $\frac{\circ}{0}$ \\
\hline 1 & Rehberlik ve Psikolojik Danışmanlık & 46 & 10,8 \\
\hline 2 & Türkçe Öğretmenliği & 31 & 7,3 \\
\hline 3 & İlköğretim Matematik Öğretmenliği & 64 & 15,1 \\
\hline 4 & İngilizce Öğretmenliği & 95 & 22,4 \\
\hline 5 & Okul Öncesi Öğretmenliği & 43 & 10,1 \\
\hline 6 & $\begin{array}{lll}\text { Bilgisayar } & \text { ve } & \text { Öğretim }\end{array}$ & 15 & 3,5 \\
\hline 7 & Edebiyat Öğretmenliği & 44 & 10,4 \\
\hline 8 & Matematik Öğretmenliği & 27 & 6,4 \\
\hline 9 & Tarih Öğretmenliği & 9 & 2,1 \\
\hline 10 & Coğrafya Öğretmenliği & 6 & 1,4 \\
\hline 11 & Felsefe Öğretmenliği & 5 & 1,2 \\
\hline 12 & Fizik Öğretmenliği & 7 & 1,6 \\
\hline 13 & Kimya Öğretmenliği & 6 & 1,4 \\
\hline 14 & Sağlık Bilgisi Öğretmenliği (Hemşirelik) & 8 & 1,9 \\
\hline 15 & Müzik Öğretmenliği & 8 & 1,9 \\
\hline 16 & Diğerleri & 11 & 2,6 \\
\hline & Toplam & 425 & 100,0 \\
\hline
\end{tabular}

Çalışma grubunun seçilmesinde lisans programlarında "Öğretim İlke ve Yöntemleri", pedagojik formasyon programlarında ise "Öğrenme Öğretme Kuram ve Yaklaşımları" derslerini alan öğretmen adayları dikkate alınmıştır. Çünkü bu dersler hem 2011-2012 hem de 2012-2013 akademik yıllarında doğrudan araştırmacı tarafından yürütülmüş olup, akademik dönemlerin bir haftasında yapılandırmacı öğrenme kuramı işlenmiştir. Bu doğrultuda çalışma grubunda yer alan öğretmen adaylarının, çalışma konusu hakkında bilgi sahibi oldukları söylenebilir.

Literatürde, ölçeğin geçerlik çalışmalarında faktör analizi gibi çok değişkenli analizlerin yapılabilmesi için ulaşılması gereken örneklem büyüklüğü konusunda farklı ölçütler ve görüşler yer almaktadır. Örneklem büyüklüğünü dikkate alan Preacher ve MacCallum (2002, Akt. Fer ve Cırık, 2006) minimum örneklem büyüklüğünün 100 ile 250 arasında olması gerektiğini belirtmiştir. Benzer bir görüşü dile getiren Tavşancıl (2006) ise geçerlik analizi sonuçlarının genellenebilmesi için örneklemin 200 ve üzerinde olmasını ileri sürmektedir. Öte yandan bazı görüşler ise ölçekte yer alan madde sayısını dikkate alarak örneklem büyüklüğü veya çalışma grubu hakkında oran vermektedir. Konuyla ilgili olarak Balcl (2011) örneklem büyüklüğünün madde sayısının birkaç katı büyük olması gerektiğini vurgularken, Bayram (2010) ise doğrulayıcı faktör analizi (DAF) yapılması için katılımcı sayısını 200'den fazla olması gerektiğine işaret etmektedir. Bu doğrultuda Preacher ve MacCallum (2002, Akt. Fer ve Cırık, 2006) ise çalışma grubunda yer alan katılımcı sayısının madde sayısından en az üç kat daha fazla olması gerektiğini ileri 
sürmektedir. Bu bağlamda bu araştırmanın çalışama grubu 425 öğretmen adayından oluştuğu için, yukarıda belirtilen görüşlerden hareketle, bu sayı araştırmanın amacı ve istatistiksel çözümleme için uygundur denilebilir.

\subsection{Veri Toplama Aracının Geliştirilmesi (Development of Data Collection Inventory)}

Öncelikle ilgili literatüre dayalı olarak ve revize edilen ölçeğin maddelerini de içerecek şekilde yapılandırmacı öğrenme kuramının göstergesi sayılabilecek 212 maddeden oluşan bir madde havuzu oluşturulmuştur. Bu süreci takiben araştırmacı ile bir alan uzmanı tarafından bu madde havuzu üzerinde derinlemesine çalışılarak 48 maddeden oluşan yeni bir taslak ölçek hazırlanmıştır. Likert türü ifadelerin ne olacağı noktasında da alanında uzman üç kişinin görüşüne başvurulmuştur. Elde edilen dönütler doğrultusunda Likert türü ifadeler (maddelere katılım seçenekleri) "5-Tamamen farkındayım", "4Oldukça farkındayım", "3-Orta düzeyde farkındayım", "2-Çok az farkındayım", "1-Hiç farkında değilim" şeklinde belirlenmiştir. Daha sonra bu taslak ölçek bir dil bilgisi uzmanın görüşüne sunulmuş ve onun görüşü doğrultusunda dört madde yeniden düzenlenmiştir.

Ölçek maddelerinin, ölçülmek istenen davranışı ölçmede nicelik ve nitelik olarak yeterli olup olmadığını belirlemek ve taslak ölçek formunun kapsam ve görünüş geçerliliğini sağlamaya yardımcı olmak için uzman görüşüne başvurulmuştur (Büyüköztürk, 2007). Öte yandan Borden'sa (2001, Akt. Yolcu, 2009) göre uzman görüşü konuya ilişkin geçerli bilginin elde edilmesinin başlangıç aşamasını oluşturmakta ve konu hakkında uzman kişilerden elde edinilen bilgi, kanıt ya da açıklamalar araştırmanın temel problemine ışık tutmaktadır.

Bu amaçla elde edilen bu taslak ölçek dokuz farklı üniversitede görev yapan ve aralarında program geliştirme, ölçme-değerlendirme ve dil uzmanı ile yapılandırmacı öğrenme konusu üzerinde çalışan 13 öğretim üyesinin görüşüne sunulmuş ve bunların içerisinden sekiz öğretim üyesi dönüt vermiştir. Uzmanlar, taslak ölçekte yer alan maddelerin kapsam geçerliğine hizmet edecek nitelik ve nicelikte olduğunu, ancak faktör analizi sonucunda madde atımı olabileceği ihtimalini dikkate alarak ölçeğe yeni maddeler eklenmesinin daha doğru olacağını beyan etmişlerdir. Uzmanların bazıları tarafından dile getirilen başka bir öneri ise, ölçekte yer alan bazı maddelerin birden fazla fikri, eylemi, önermeyi içerdiğini, bu nedenle her maddenin bir fikri, düşünceyi, eylemi vb. belirtmesi gerektiği yönünde olmuştur. Ancak ölçek geliştirilen alan kapsam açısından oldukça geniş bir konu yelpazesini içerisine almaktadır. Bu noktada araştırmacı bir yandan uzmanların bu görüşlerini dikkate almaya çalışmış, bir yandan da makul sayıda maddeden oluşan bir ölçek geliştirme amacını taşımıştır. Bu nedenle birbirini destekleyici, neden-sonuç ilişkisinin bulunduğu, biri olmadan diğerinin olmayacağı vb. durumların olduğu yerlerde bir maddede birbiriyle ilintili birden fazla fikir, eylem, önermenin olması normal görülmüştür. Ayrıca bu durum görüşü alınan bazı uzmanların görüşleriyle de tutarlıdır.

Uzmanların görüşleri doğrultusunda taslak ölçekte yer alan maddelerin bazıları olumsuz yapıya çevrilmiş ve taslak ölçeğe sekiz madde daha eklenerek ölçeğin madde sayısı 56'ya çıkarılmıştır. Elde edilen taslak ölçek bu şekliyle cümle hataları ve ifade yanlışlıklarını düzeltmek amacıyla yeniden iki dil bilgisi uzmanının görüşüne sunulmuş ve dönütler doğrultusunda ölçeğin bir maddesi anlam açısından daha net ve anlaşılır biçimde yeniden yazılmıştır. Bu işlemi takiben 2012-2013 akademik yılı güz döneminde Mevlana Üniversitesi Eğitim Fakültesi Türkçe öğretmenliği lisans programında öğrenim gören 
28 kişilik öğretmen adayına ölçeğin ön uygulaması yaptırılmıştır. Elde edilen dönütler, ölçeğin bu şekliyle kullanılabileceği yönünde olmuştur. Bu sonuçlar doğrultusunda taslak ölçek yapı geçerliği ve güvenirlik çalışmaları için çalışma grubunda yer alan 425 öğretmen adayına uygulanmıştır.

\subsection{Veri Toplama Süreci ve Ölçeğin Uygulanması (Data Collection Process and Application of the Scale)}

Ölçek, araştırmacı tarafından ve katılımcıların gönüllülük ilkesine göre çalışma grubuna uygulanmıştır. Uygulanmadan önce ölçeğin amacı ve uygulanış şekli hakkında çalışma grubuna bilgi verilmiş ve onlara soruları içtenlikle yanıtlamalarının önemi açıklanmıştır. Örneğin, ölçekte verilen maddede belirtilen önermenin tamamen farkında ise katılımcllardan maddenin karşısında yer alan ilgili kutucuğa "5" rakamını, hiç farkında değilse "1" rakamını yazmaları istenmiştir. Ayrıca bu ve benzer uyarılar ölçeğin yönergesinde de sunulmuştur. 0328 Aralık 2012 tarihleri arasında uygulanan ölçeğin uygulama süresi katılımcı başı ortalama 25 ile 35 dakika arasında sürmüştür.

Tekrar test ile eş değer test uygulaması 2012-2013 akademik yılı güz döneminde Mevlana Üniversitesi Eğitim Fakültesi Türkçe öğretmenliği lisans programında ikinci sınıf düzeyinde öğrenim gören 40 öğretmen adayı (29 kadın, 11 erkek) üzerinde yürütülmüştür. Tekrar test 1 ile eş değer test uygulaması aynı anda ve 5 Kasım 2012 tarihinde, tekrar test 2 ise 30 Kasım 2012 tarihinde yapılmıştır. Tekrar test ile eş değer test uygulamasına katılan öğretmen adayları, ölçeğin asıl uygulamasına dâhil edilmemiştir. Eşdeğer form olarak Arkün ve Aşkar (2010) tarafından geliştirilen "Yapılandırmacı Öğrenme Ortamlarını Değerlendirme ölçeği" kullanılmıştır. "Kesinlikle katılmıyorum: 1...7: Kesinlikle katılıyorum" olarak yedili likert türünde hazırlanan ölçek, altı faktör ve 28 maddeden oluşmaktadır. Ölçeğin faktörleri, 890 ile, 754 arasında değişen Cronbach alpha iç tutarlık değerine sahipken bu değer ölçeğin genelinde ise, 961'dir.

\subsection{Verilerin Analizi (Data Analysis)}

ölçeğin yapı geçerliliğini test etmek ve aynı niteliği ölçen değişkenleri bir araya getirerek, ölçmeyi az sayıda faktör ile açıklamak amacıyla faktör analizinin yapılması gerekmektedir. Açımlayıcı faktör analizinde ölçekte yer alacak maddelerin belirlenmesinde maddelerin öz değerlerinin 1 ve maddelerin faktör yük değerinin en az ,30 olmasına, öte yandan maddelerin tek bir faktörde yer alması ve iki faktörde yer alan faktörler arasında ise en az ,10'luk bir farkın olmasına dikkat edilmiştir (Büyüköztürk, 2007). Bunun yanında yapı geçerliliği esnasında 25 derecelik varimax eksen döndürmesi yapılmıştır.

Açımlayıcı faktör analizinden elde edilen madde-faktör yapısı hem birinci düzey hem de ikinci düzey doğrulayıcı faktör analizi (DFA) ile model uyumu test edilmiştir. Birinci düzey DFA'da ölçeği oluşturan gizil (örtük/latent) değişkenler (bir bakıma ölçeğin faktörleridir) ve bu değişkenleri oluşturan gözlenen değişkenler (bir bakıma ölçeğin veya faktörlerin maddeleridir) arasında korelasyon yada koveryans matrisi oluşturulur. İkinci düzey $\mathrm{DFA}^{\prime}$ da ise ölçeğin geneli de modele ikinci düzey gizil değişken olarak eklendiği için, bu ikinci düzey DFA'da tüm gözlenen değişkenlerde açıklanamayan varyansın yanı sıra birinci düzey örtük değişkenlerde de ikinci düzey örtük değişkenler tarafından açıklanamayan varyans elde edilebilir. Bu nedenle ikinci tür DFA sonucunda elde edilen model daha anlamlıdır (Şimşek, 2007).

Doğrulayıcı faktör analizinde model parametrelerinin tahmin edilmesinde maksimum olabilirlik tahmin yöntemi kullanılmıştır. Model 


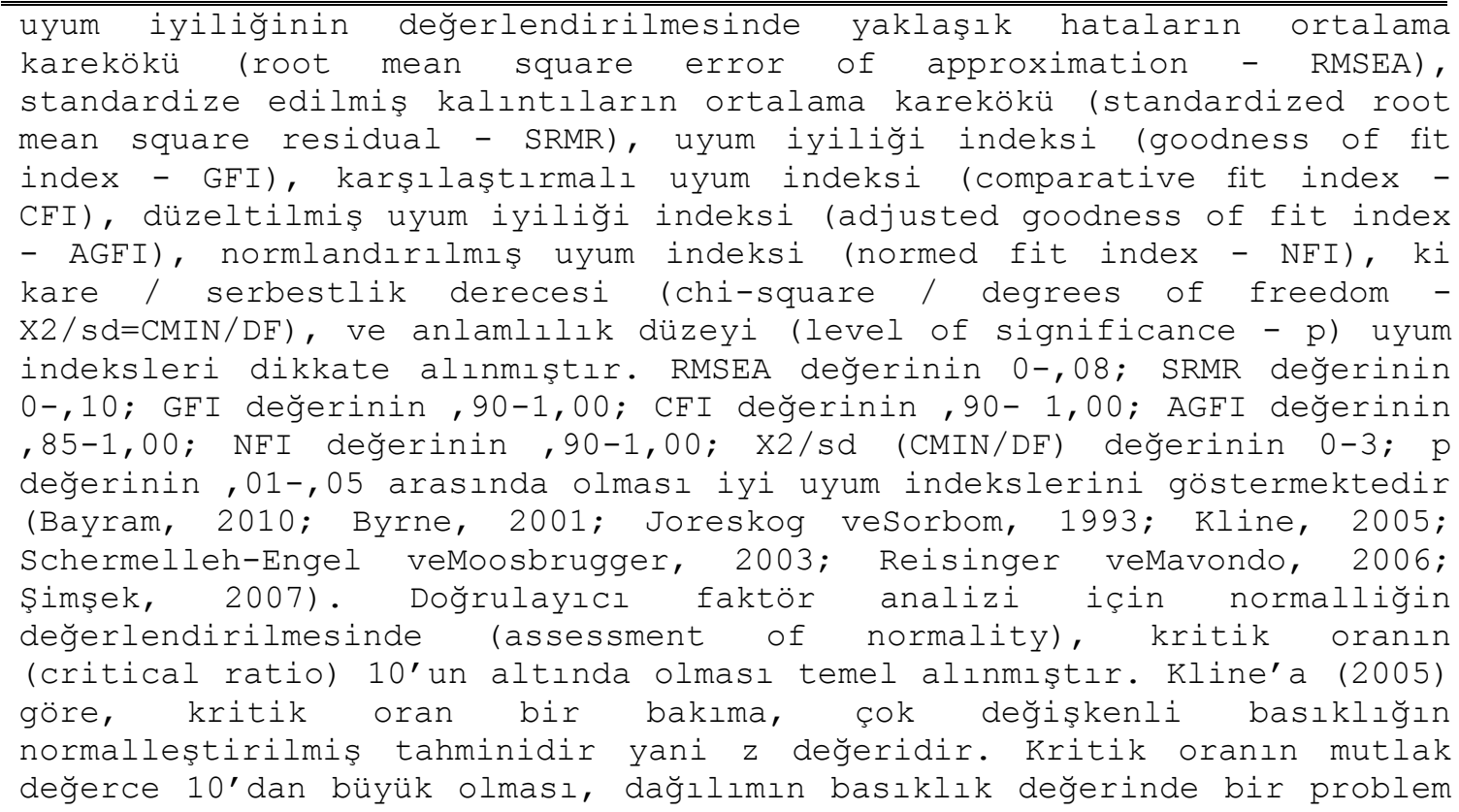
olduğunu ortaya koymaktadır.

Ölçeğin güvenirliğine Cronbach Alpha iç tutarlık katsayısı, eşdeğer (paralel / alternatif) form, tekrar test ve iki yarı test (testi yarılama) güvenirliği ile bakılmıştır (Balcı, 2011; Büyüköztürk ve diğ, 2010; Ellez, 2009). Bu bağlamda Büyüköztürk (2007) tekrar test güvenirliğinin, bir testin aynı gruba ortalama dört hafta aralıkla iki kez uygulanmasından elde edilen puanlar arasındaki korelasyon ile açıklandığını ve elde edilen korelasyon katsayısının testin zamana bağlı olarak ne derece kararlı ölçümler verdiğini yorumlamak için kullanıldığını vurgulamaktadır. Öte yandan Tavşancıl (2006) ise, tekrar testin iki-altı hafta aralıkla en az otuz kişiye ölçeğin uygulanması gerektiğini belirtmektedir. Bu çalışmada tekrar test, yaklaşık dört haftalık bir ara ile yapılmıştır. Eş değer test güvenirliğinde, aynı özelliği ölçemeye yönelik hazırlanan iki benzer formun bir gruba aynı veya farklı zamanlarda uygulanmasindan elde edilen test puanları arasındaki korelasyon değerleri dikkate alınmaktadır. İki yarı test güvenirliğinde ise bir testin iki yarısı (tek numaralı maddeler ve çift numaralı maddeler veya testin ilk yarısı ile son yarısı vb.) arasındaki korelasyon değerine bakılarak iki yarı testin puanları arasındaki tutarlılığa bakılmaktadır.

Cronbach Alpha değerinin, 70 ve üzeri olması güvenirlik için yeterlidir (Büyüköztürk, 2007). Ancak Kayış'a (2006) göre, Cronbach Alpha değerinin, 80'den büyük olması ölçeğin yüksek derecede güvenilir olduğunu göstermektedir. Bu nedenle bu çalışmada güvenirlik değeri , 80 ve üzeri olarak kabul edilmiştir. Eşdeğer form, tekrar test ve iki yarı test güvenirliğini ortaya koymak için korelasyon değerleri dikkate alınmıştır. Büyüköztürk, Çokluk ve Köklü'ye (2012) göre test puanları arasındaki ilişki korelasyon katsayısıyla bulunur ve korelasyon katsayısının, 70 ve üzeri olması, iki değişken arasında yüksek düzeydeki bir ilişkinin olduğunu göstermektedir. Bunun yanı sıra değişkenlerin sürekli bir dağılıma sahip ancak normal dağılım göstermediği durumlarda da iki değişken arasındaki ilişkiyi açıklamak için Spearman Brown sıra farkları korelasyonu kullanılabilir. Ortaya çıkan korelasyon katsayısının mutlak değer olarak, 70 ile 1,00 arasında bir değerde olması, iki değişken arasındaki ilişkinin olumlu ve yüksek düzeyde olduğunu göstermektedir (Büyüköztürk, 2007). Bu çalışmada değişkenler arasındaki korelasyon değeri için, 70 ve üzeri 


\begin{abstract}
temel alınmıştır. Araştırmada katılımların demografik özellikleri, açımlayıcı faktör analizi ve iç tutarlılık katsayılarının belirlenmesinde SPSS 16.0, doğrulayıcı faktör analizinin yapılmasında ise AMOS 17.0 paket programları kullanılmıştır.
\end{abstract}

\title{
5. BULGULAR (FINDINGS)
}

Çalışmada istatistiksel işlemler olarak sırayla, açımlayıcı faktör analizi, birinci düzey doğrulayıcı faktör analizi, ikinci düzey doğrulayıcı faktör analizi, iç tutarlılık katsayıları, eşdeğer (benzer / paralel) form, tekrar test ve iki yarı test güvenirliği yapılmıştır. Bulgular istatistiksel işlem sırasına göre sunulmuştur.

\section{1. Ölçeğin Geçerliğine İlişkin Bulgular (Findings abaout Validity of Scale)}

- Açımlayıcı Faktör Analizi (Exploratory Factor Analyses): Faktör analizi, birbiriyle ilişkili çok sayıdaki değişkeni bir araya getirerek az sayıda ilişkisiz ve kavramsal olarak anlamlı yeni faktörler bulmayı amaç edinen, ölçek maddelerinin ölçtüğü ve faktör adı verilen yapı ya da yapıları ortaya çıkarmak için kullanılan bir analizdir (Balcı, 2011; Büyüköztürk, 2007; Turgut ve Baykul, 1992). Ölçeğin yapı geçerliğini saptamak için faktör analizi yapılmıştır. Tavşancıl'a (2006) göre faktör analizinde, örneklemden elde edilen verilerin yeterliğini belirlemek için Kaiser-Meyer-olkin (KMO) testi yapılmalıdır. Büyüköztürk'e (2007) göre KMO sonucunun, 60'dan büyük olması ve Bartlett testinin anlamlı çıkması, veri setinin faktör analizi yapılması için uygun olduğunu göstermektedir. Konuyla ilgili olarak Kalaycı (2006) ve Tavşancıl (2006) ise elde edilen verilerin yeterliğinin saptanmasında KMO değerinin, 90 ve üzerinde olmasının mükemmel bir sonuç olduğunu belirtmektedir. Verilerin analizi sonucunda ölçeğin KMO değerinin, 947 olduğu belirlenmiştir (revize edilen ölçeğin KMO değeri ise, 890'dır). Hem KMO değeri hem de Bartlett Sphericity testinden elde edilen sonuçlar $(x 2=1,213 \mathrm{E} 4, \mathrm{df}=1540, \mathrm{p}=, 000)$ verilerin faktör analizi yapmaya uygun olduğuna işaret etmektedir. Kulaksızloğlu, Dilmaç, Ekşi ve Otrar (2003) ile Aşkar ve Dönmez'in (2004) de belirttiği gibi, bu ve buna benzer değerler, örneklem büyüklüğünün ve elde edilen verilerin seçilen analiz için uygun ve yeterli olduğuna işaret etmektedir. Başka bir deyişle bu değerler, deneme uygulamasından elde edilen verilerin faktör analizine tabi tutulabileceğini göstermektedir.

Büyüköztürk'e (2007) göre, faktör analizinde aynı yapıyı ölçmeyen maddelerin ayıklanmasında ve faktör sayısına karar verilmesindeki özdeğer, faktör yük değeri ve iki faktör yükü arasındaki fark temel alınmalıdır. Özdeğeri 1 ve daha yüksek olan maddeler önemli faktörlerdir ve açıklanan varyans oranının yüksek olması, ilgili yapıyı iyi ölçtüğünün göstergesidir. Faktörün tanımladığı maddeyi ölçmesi için o faktörle olan ilişkisini gösteren faktör yük değerinin, 45 ve daha yüksek olması tercih sebebidir. Ancak az sayıdaki madde için yük değeri , 30'a kadar düşürülebilir. Bu çalışmada da faktör yük değeri , 30 olarak temel alınmıştır. Ayrıca yüksek iki faktör yükü arasındaki fark ise en az, 10 olmalıdır. Çünkü çok faktörlü bir yapıda birden fazla yüksek yük değeri veren madde binişik maddedir ve ölçekten çıkarılması gerekmektedir. Bu çalışmada bir maddenin bir faktörde yer alması için yukarıda belirtilen ilkeler temel alınmıştır. Açımlayıcı faktör analizi sonucunda 
elde edilen faktörler ve bu faktörlerde yer alan maddelerin faktör yük değerleri Tablo 2'de yer almaktadır.

Tablo 2. Maddelerin açımlayıcı faktör analiz sonuçları (Table 2. Result of exploratory factor analyses about items)

\begin{tabular}{|c|c|c|c|c|}
\hline 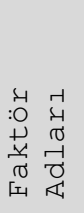 & 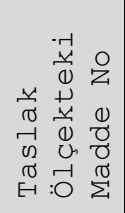 & $\begin{array}{l}0 \\
z \\
0 \\
0 \\
0 \\
0 \\
\Sigma \\
\Sigma\end{array}$ & Maddeler & 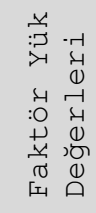 \\
\hline \multirow{6}{*}{ 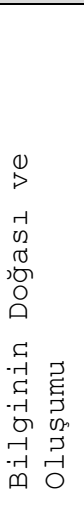 } & 8 & 1 & $\begin{array}{l}\text { Yeni bilgi; öğrencinin önceki bilgisi, değer } \\
\text { yargısı, yaşantısı ve deneyimine göre oluşur. }\end{array}$ &, 740 \\
\hline & 1 & 2 & $\begin{array}{l}\text { Bilgiyi öğrenmede öğrencinin şema, özümseme, uyma } \\
\text { gibi bilişsel şemaları kullanması önemlidir. }\end{array}$ &, 680 \\
\hline & 2 & 3 & $\begin{array}{l}\text { Bilginin doğruluğu, gerçekliği ve faydası bireyden } \\
\text { bireye değişir. }\end{array}$ &, 676 \\
\hline & 5 & 4 & $\begin{array}{l}\text { Deney, gözlem ve yaşantı gibi birincil bilgi } \\
\text { kaynakları bilginin kazanılmasında temel rol } \\
\text { oynar. }\end{array}$ &, 653 \\
\hline & 5 & 5 & $\begin{array}{l}\text { İli, tutum, değer, algı gibi bireysel özellikler } \\
\text { bilginin oluşturulmasında önemli bir etkiye } \\
\text { sahiptir. }\end{array}$ &, 645 \\
\hline & 1 & 6 & $\begin{array}{l}\text { Bilgi, öğrenci tarafından anlamlandırılır, } \\
\text { yorumlanır, geliştirilir ve yeniden inşa edilir. }\end{array}$ &, 579 \\
\hline \multirow{6}{*}{ 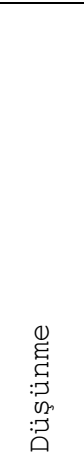 } & 8 & 7 & $\begin{array}{l}\text { Öğrenciler düşünme, akıl yürütme ve sorun çözme } \\
\text { becerilerini sorgular. }\end{array}$ &, 715 \\
\hline & 3 & 8 & $\begin{array}{l}\text { Öğrencilerin yaratıcı, sorgulayıcı, analitik ve } \\
\text { eleştirel düşünme yeteneklerinin gelişmesi } \\
\text { esastır. }\end{array}$ &, 707 \\
\hline & 9 & 9 & $\begin{array}{l}\text { Öğrenci araştırma yapmaya ve problem çözmeye } \\
\text { teşvik edilir. }\end{array}$ &, 695 \\
\hline & 0 & 0 & $\begin{array}{l}\text { Problemlere çözüm yolları geliştirmede öğrenciye } \\
\text { rehberlik edilir. }\end{array}$ &, 634 \\
\hline & 4 & 1 & $\begin{array}{l}\text { Farklı düşünceler zenginlik kabul edilir ve } \\
\text { desteklenir. }\end{array}$ &, 595 \\
\hline & 2 & 2 & $\begin{array}{l}\text { Öğrenci konu, olay veya olgulara, sorgulayıcı ve } \\
\text { eleştirel bakış açısıyla yaklaşır. }\end{array}$ &, 583 \\
\hline \multirow{6}{*}{ 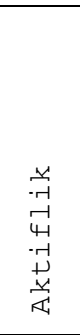 } & 7 & 3 & Yaparak ve yaşayarak öğrenme temel ilkedir. &, 820 \\
\hline & 1 & 4 & $\begin{array}{l}\text { Sınıf içi uygulamalarda, öğrenci aktifliğinin } \\
\text { desteklenmesi ve geliştirilmesi esastır. }\end{array}$ &, 762 \\
\hline & 8 & 5 & $\begin{array}{l}\text { Öğrenci, bilgiyi araştırır, yorumlar, keşfeder ve } \\
\text { yeniden oluşturur. }\end{array}$ &, 728 \\
\hline & 3 & 6 & Öğrenci meraklı, girişimci ve aktiftir. &, 678 \\
\hline & 4 & 7 & Bilgi, çevre ile etkileşim kurarak oluşturulur. &, 672 \\
\hline & 5 & 8 & $\begin{array}{l}\text { Daha çok üst düzey (analiz, değerlendirme, sentez) } \\
\text { kazanımlara uygun öğrenme yaşantısı sunulur. }\end{array}$ &, 626 \\
\hline \multirow{8}{*}{ 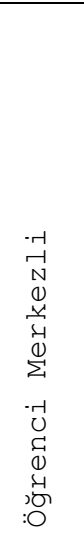 } & 2 & 9 & $\begin{array}{l}\text { Bireysel farklılıkları dikkate almak, ders işleme } \\
\text { sürecinde önemli bir unsurdur. }\end{array}$ &, 735 \\
\hline & 0 & 0 & $\begin{array}{l}\text { Öğrenme sürecinin merkezinde öğrencinin ilgisi, } \\
\text { isteği, ihtiyacı ve hedefi yer alır. }\end{array}$ &, 721 \\
\hline & 3 & 1 & $\begin{array}{l}\text { "Öğrenci nasıl daha iyi öğrenir?" sorusu dikkate } \\
\text { alınır. }\end{array}$ &, 629 \\
\hline & 4 & 2 & $\begin{array}{l}\text { Bilgi birikimi ve öğrenme şekli bakımından } \\
\text { öğrenciler birbirinden farklı özellik taşır. }\end{array}$ &, 603 \\
\hline & 7 & 3 & $\begin{array}{l}\text { Öğrenciyi tanımada ilgi, yetenek ve hazır } \\
\text { bulunuşluk düzeyi gibi birçok değişken dikkate } \\
\text { alınır. }\end{array}$ &, 597 \\
\hline & 2 & 4 & Öğrenci kendi öğrenme sürecini planlar ve uygular. &, 543 \\
\hline & 3 & 5 & $\begin{array}{l}\text { Etkinliklerin planlanması, uygulanması ve } \\
\text { değerlendirilmesi öğrenciyle yapılır. }\end{array}$ &, 508 \\
\hline & 9 & & Öğretmen, öğrencinin öğrenme hızına ve çalışma &, 457 \\
\hline
\end{tabular}


Yesilyurt, $E$.

NWSA-Education Sciences, 1C0588, 8, (2), 285-307.

\begin{tabular}{|c|c|c|c|c|}
\hline & & 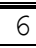 & biçimine müdahale etmez. & \\
\hline \multirow{8}{*}{ 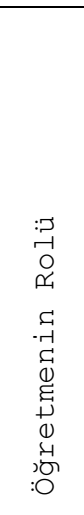 } & 1 & 7 & $\begin{array}{l}\text { Öğretmen, öğrencinin niçin ve nasıl öğrendiğine } \\
\text { önem verir. }\end{array}$ &, 812 \\
\hline & 6 & 8 & $\begin{array}{l}\text { Öğretmen, öğrenciyi yeni şeyler ortaya koymaya } \\
\text { teşvik eder. }\end{array}$ &, 792 \\
\hline & 6 & 9 & Öğretmen, öğrenciye hazır bilgi vermez. &, 784 \\
\hline & 9 & 0 & Öğretmen, kendini günceller ve değerlendirir. &, 773 \\
\hline & 9 & 1 & $\begin{array}{l}\text { Öğretmen, bilgi, beceri, duygu ve sezgisini } \\
\text { öğrenciye aşılamaz. }\end{array}$ &, 633 \\
\hline & 5 & 2 & $\begin{array}{l}\text { Öğretmen, öğrencinin farklı bakış açıları } \\
\text { kazanmasına yardımcı olur. }\end{array}$ &, 589 \\
\hline & 2 & 3 & $\begin{array}{l}\text { Öğretmen, öğrenciyle keşfeder, araştırır ve } \\
\text { öğrenir. }\end{array}$ &, 565 \\
\hline & 6 & 4 & $\begin{array}{l}\text { Öğretmen, eğitim-öğretim sürecinde rehber } \\
\text { konumundadır. }\end{array}$ &, 488 \\
\hline \multirow{10}{*}{ 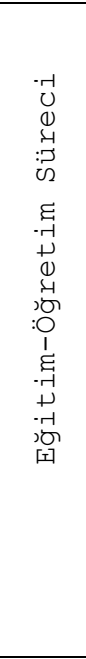 } & 5 & 5 & $\begin{array}{l}\text { Öğrencinin dikkat, ilgi, merak ve araştırma arzusu } \\
\text { canlı tutulur. }\end{array}$ &, 852 \\
\hline & 6 & 6 & $\begin{array}{l}\text { İçeriğin ne zaman, nasıl ve ne kadar sürede } \\
\text { işleneceği konusunda program esnektir. }\end{array}$ &, 825 \\
\hline & 5 & 7 & $\begin{array}{l}\text { Farklı öğretim model, strateji, yöntem ve } \\
\text { teknikler kullanılır. }\end{array}$ &, 780 \\
\hline & 8 & 8 & $\begin{array}{l}\text { İslenen konunun, diğer derslerin konularıyla } \\
\text { ilişkisi kurulur. }\end{array}$ &, 727 \\
\hline & 8 & 9 & $\begin{array}{l}\text { Ağırlıklı olarak öğrencinin aktif olduğu öğretim } \\
\text { yöntem ve teknikleri kullanılır. }\end{array}$ &, 705 \\
\hline & 1 & 0 & $\begin{array}{l}\text { Sorgulama, araştırma yapma ve problem çözme, } \\
\text { eğitim-öğretim sürecinin temel unsurlarıdır. }\end{array}$ &, 684 \\
\hline & 0 & 1 & Öğrenme ortamında çeşitli etkinlikler düzenlenir. &, 653 \\
\hline & 2 & 2 & $\begin{array}{l}\text { İçerik, öğrencinin ilgisine ve gerçek yaşamına } \\
\text { uygun oluşturulur. }\end{array}$ &, 574 \\
\hline & 0 & 3 & $\begin{array}{l}\text { Eğitim-öğretim sürecine aile, arkadaş, sosyal ve } \\
\text { fiziksel çevre katılır. }\end{array}$ &, 516 \\
\hline & 4 & 4 & Eğitim-öğretim süreci demokratik ve insancıldır. &, 495 \\
\hline \multirow{6}{*}{ 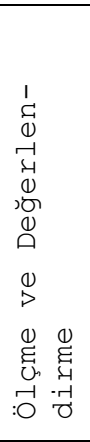 } & 1 & 5 & $\begin{array}{l}\text { Öğrenci başarısı, farklı ölçme ve değerlendirme } \\
\text { yöntemleriyle değerlendirilir. }\end{array}$ &, 670 \\
\hline & 4 & 6 & $\begin{array}{l}\text { Geleneksel ve tamamlayıcı ölçme ve değerlendirme } \\
\text { yöntemleri birlikte kullanılır. }\end{array}$ &, 628 \\
\hline & 7 & 7 & $\begin{array}{l}\text { Ölçme ve değerlendirmede süreç ve sonuç birlikte } \\
\text { dikkate alınır. }\end{array}$ &, 535 \\
\hline & 7 & 8 & $\begin{array}{l}\text { Ölçme ve değerlendirme, öğretmen ve öğrenci } \\
\text { işbirliği ile gerçekleşir. }\end{array}$ &, 503 \\
\hline & 9 & 9 & $\begin{array}{l}\text { Ölçme ve değerlendirmeyle öğrenci bilgisinin nasıl } \\
\text { ve ne ölçüde değiştiği tespit edilir. }\end{array}$ &, 487 \\
\hline & 6 & 0 & $\begin{array}{l}\text { Ölçme ve değerlendirme, yargılama amaçlı değil, } \\
\text { bilgilendirme amaçlı yapılır. }\end{array}$ &, 462 \\
\hline \multirow{6}{*}{ 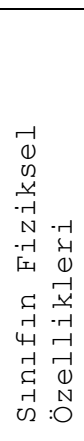 } & 6 & 1 & $\begin{array}{l}\text { Sınıf ilgi, yetenek ve başarı gibi benzer } \\
\text { nitelikteki öğrencilerden oluşmaz. }\end{array}$ &, 784 \\
\hline & 4 & 2 & $\begin{array}{l}\text { Sınıflar, Türkçe, matematik ve tarih sınıfları } \\
\text { gibi branşlara ayrılarak düzenlenir. }\end{array}$ &, 778 \\
\hline & 3 & 3 & $\begin{array}{l}\text { Sınıflar, teorik ve uygulamalı dersleri birlikte } \\
\text { işlemeye uygundur. }\end{array}$ &, 683 \\
\hline & 7 & 4 & $\begin{array}{l}\text { Sınıflar, farklı öğretim yöntemlerinin kullanımı } \\
\text { için düzen ve biçim açısından esnektir. }\end{array}$ &, 528 \\
\hline & 0 & 5 & $\begin{array}{l}\text { Sınıflar kaynak, materyal ve öğretim teknolojileri } \\
\text { bakımından zengindir. }\end{array}$ &, 512 \\
\hline & 3 & 6 & $\begin{array}{l}\text { Sınıflarda, öğrencinin araştırma } \\
\text { destekleyici materyaller mevcuttur. }\end{array}$ &, 476 \\
\hline
\end{tabular}

Tablo 2'den de görüleceği üzere açımlayıcı faktör analizi soncunda, ölçeğin 56 madde ve sekiz faktörlü bir yapıya sahip olduğu tespit edilmiştir (benzer bir şekilde revize edilen ölçek ise 58 madde ve yedi faktörden oluşmaktadır). Elde edilen bu sekiz faktörü 


\begin{abstract}
oluşturan maddelerin ortak yanlarından yola çıkılarak, faktör adlarının sırasıyla "bilginin doğası ve oluşumu", "düşünme", "aktiflik", "öğrenci merkezli", "öğretmenin rolü", "eğitim-öğretim süreci", "ölçme ve değerlendirme" ile "sınıfın fiziksel özellikleri" olarak tanımlanması uygun görülmüştür. Bu noktada yeniden yapılandırılan ölçeğin, revize edilen ölçekten farkı "bilginin doğası ve oluşumu" ile "sınıfın fiziksel özellikleri" adlı faktörlerin elde edilmesidir. Alanyazındaki kaynaklar (Arslan, 2007; Aydın, 2007; Brooks ve Brooks, 1999; Gürol, 2002; Yaşar, 1998; Yurdakul, 2007) göz ününe alındığında, yapılandırmacı öğrenmenin özünde bilgi, öğrenme, öğrenci, öğretmen, öğretim süreci, değerlendirme, yaratıcılık, aktiflik ve düşünmeye vurgu yapıldığı görülmektedir. Bu doğrultuda geliştirilen ölçeğin boyutlandırılmasında (faktörlere ad verilmesinde) alanyazındaki bu tespit de etkili olmuştur. Ölçekte yer alan maddelerin faktör yükleri, 852 ile, 457 arasında değişmektedir (revize edilen ölçekte yer alan maddelerde ise faktör yük değerleri ,741 ile, 315 arasında yer almaktadır). Madde faktör yükleri, sınır değeri olarak kabul edilen, 30'un üzerinde olduğundan, ayrıca madde faktör yükleri arasında bir binişikliğin olmadığı görüldüğünden, açımlayıcı faktör analizi sonuçlarına göre ölçeğin sekiz faktörlü yapısının uygun olduğu söylenebilir. Ölçekte yer alan sekiz faktör toplam varyansın $\% 56,907^{\prime}$ sini açıklamaktadır (revize edilen ölçekte ise bu oran o45,948'dir). Bu değerler ölçeğin yapılandırmacı öğrenme kuramına ilişkin bilişsel farkındalığı iyi bir şekilde açıkladığını göstermektedir. Elde edilen değerlerin ve yapının model uyumu testine ise doğrulayıcı faktör analizi ile bakılmıştır. Başka bir deyişle açımlayıcı faktör analizi sonucunda elde edilen yapı, doğrulayıcı faktör analizi ile test edilmiştir.
\end{abstract}

- Doğrulayıcı Faktör Analizi (Confirmatory Factor Analyses) : Ölçeğin doğrulayıcı faktör analizi (DFA), birinci düzey ve ikinci düzey doğrulayıcı faktör analizleri ile gerçekleştirilmiştir. Ölçeğin birinci düzey doğrulayıcı faktör analizi sonucunda, normalliğin değerlendirilmesi dikkate alındığında, multivariate (mardia) değerleri açısından kritik oran (c.r.) 30,342'dir. Yapılan birinci düzey doğrulayıcı faktör analizi modifikasyon önerileri doğrultusunda ve Şekil 1'de yer aldığı üzere, 27. ile 33., 36. ile 37., 39. ile 40., 47. ile 48., 54. ile 55. maddeler arasında modifikasyon (iyileştirme/düzeltme) yapılmıştır. Bu durumda ölçeğin birinci düzey doğrulayıcı faktör analizi sonuçları dikkate alındığında ölçeğin fit değerleri RMSEA =,047; $\quad \mathrm{SRMR}=, 0425 ; \quad \mathrm{CMIN} / \mathrm{DF}$ $(\mathrm{X} 2 / \mathrm{sd})=1,965 ; \quad \mathrm{GFI}=, 912 ; \mathrm{CFI}=, 956 ; \quad \mathrm{AGFI}=, 875$ ve NFI=,909 şeklinde ortaya çıkmıştır. Bu sonuç, birinci düzey DFA uyum indekslerinin kabul edilebilir ve istenilen düzeyde olduğunu göstermektedir.

Ölçeğin ikinci düzey doğrulayıcı faktör analizi sonucunda, normalıiğin değerlendirilmesi dikkate alındığında, multivariate (mardia) değerleri açısından kritik oranın (c.r.) 35,543 olduğu tespit edilmiştir. İkinci düzey DFA modifikasyon önerileri doğrultusunda ve Şekil 2'de yer aldığı üzere, 8. ile 11., 21. ile 25., 27. ile 33., 36. ile 37., 39. ile 40., 47. ile 48., 54. ile 55. maddeler arasında modifikasyon yapılmıştır. Bu modifikasyon sonucunda, ikinci düzey DFA sonuçları dikkate alındığında ölçeğin fit değerleri RMSEA=,052; SRMR=,0506; $\mathrm{CMIN} / \mathrm{DF} \quad(\mathrm{X} 2 / \mathrm{sd})=2,107 ; \mathrm{GFI}=, 908 ; \mathrm{CFI}=, 953 ; \mathrm{AGFI}=, 854$ ve $\mathrm{NFI}=, 914$ olarak elde edilmiştir. Bu sonuç, ikinci düzey DFA fit değerlerinin kabul edilebilir ve istenilen düzeyde olduğuna 
işaret etmektedir. Hem birinci düzey hem de ikinci düzey DAF fit değerleri dikkate alındığında ölçeğin yapı geçerliğinin sağlandığı ifade edilebilir. Başka bir deyişle, geçerlik çalışmaları sonucunda ulaşılan bulgular, ölçeğin psikometrik özellikleri bakımından kullanılabilir olduğuna işaret etmektedir. 


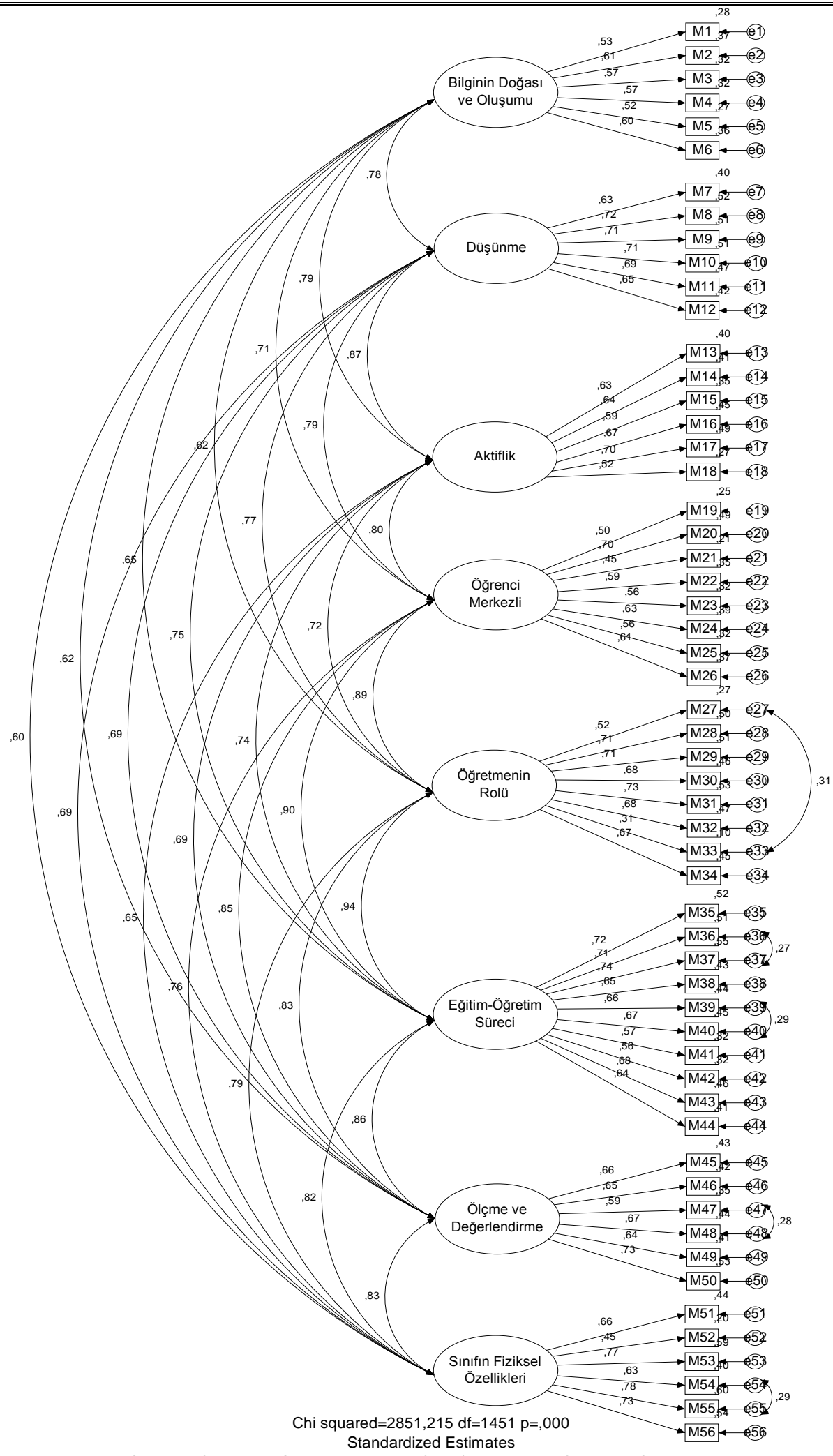

$\mathrm{GFI}=, 912 \mathrm{CFI}=, 956 \mathrm{AGFI}=, 875 \mathrm{NFI}=, 909 \mathrm{CMIN} / \mathrm{DF}=1,965 \mathrm{RMSEA}=, 047 \mathrm{SRMR}=, 0425$

Şekil 1. Birinci düzey doğrulayıcı faktör analizi ve sekiz faktör modeli

(Figure 1. Confirmatory factor analyses at the first-order and eight factors model) 


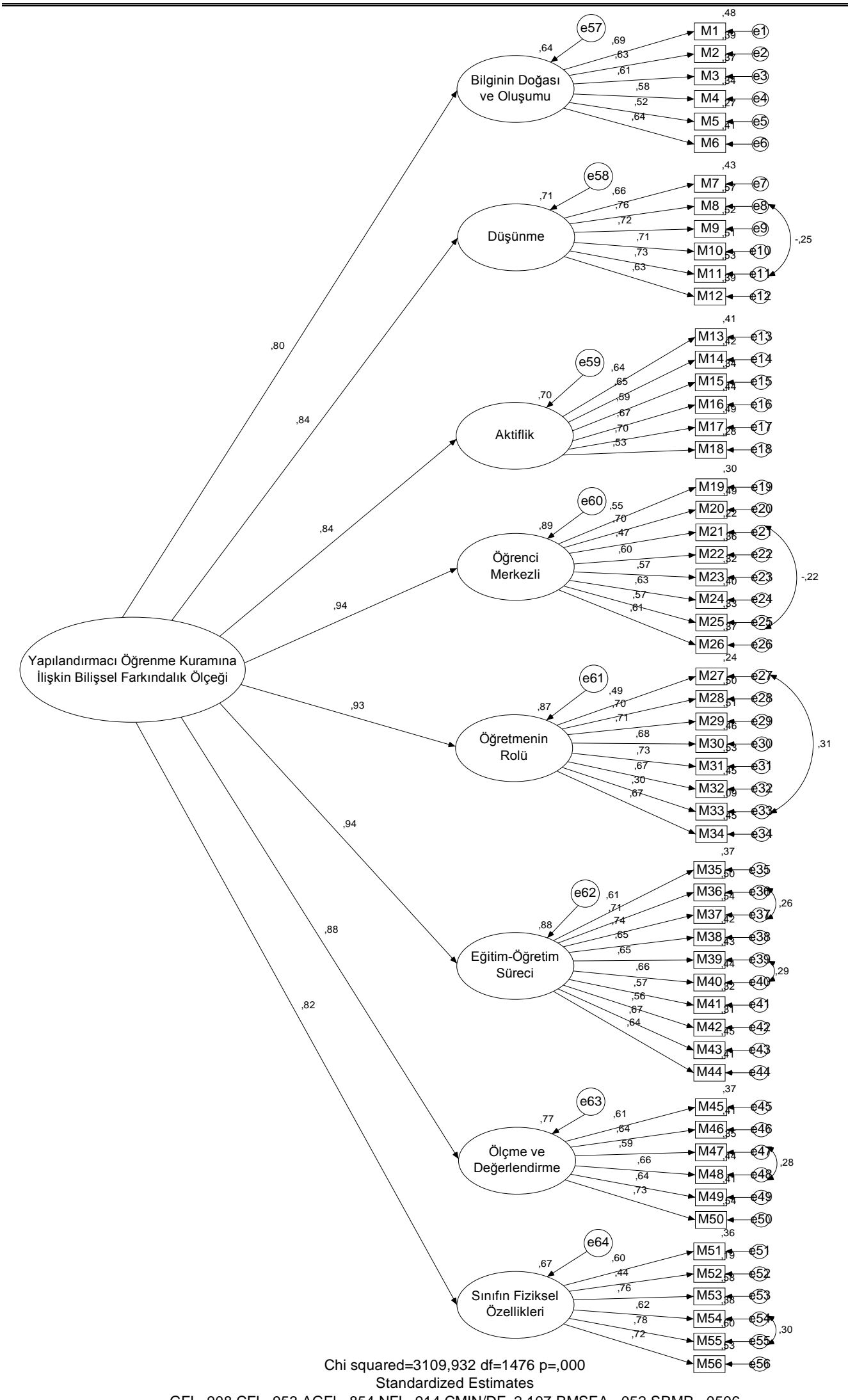

$\mathrm{GFI}=, 908 \mathrm{CFI}=, 953 \mathrm{AGFI}=, 854 \mathrm{NFI}=, 914 \mathrm{CMIN} / \mathrm{DF}=2,107 \mathrm{RMSEA}=, 052 \mathrm{SRMR}=, 0506$

Şekil 2. İkinci düzey doğrulayıcı faktör analizi modeli

(Figure 2. Confirmatory factor analyses at the second-order) 


\section{2. Ölçeğin Güvenirliğine İlişkin Bulgular (Findings abaout Reliability of Scale)}

Ölçeğin güvenirliğini test etmek için iç tutarlığı ifade eden Cronbach Alpha'nın yanı sıra eşdeğer (paralel / benzer) test, tekrar test ve iki yarı test güvenirliği analizleri yapılmış ve elde edilen sonuçlar Tablo 3'te verilmiştir.

Tablo 3. Ölçeğin güvenirlik analiz sonuçları

(Table 3. Result about reliability of scale)

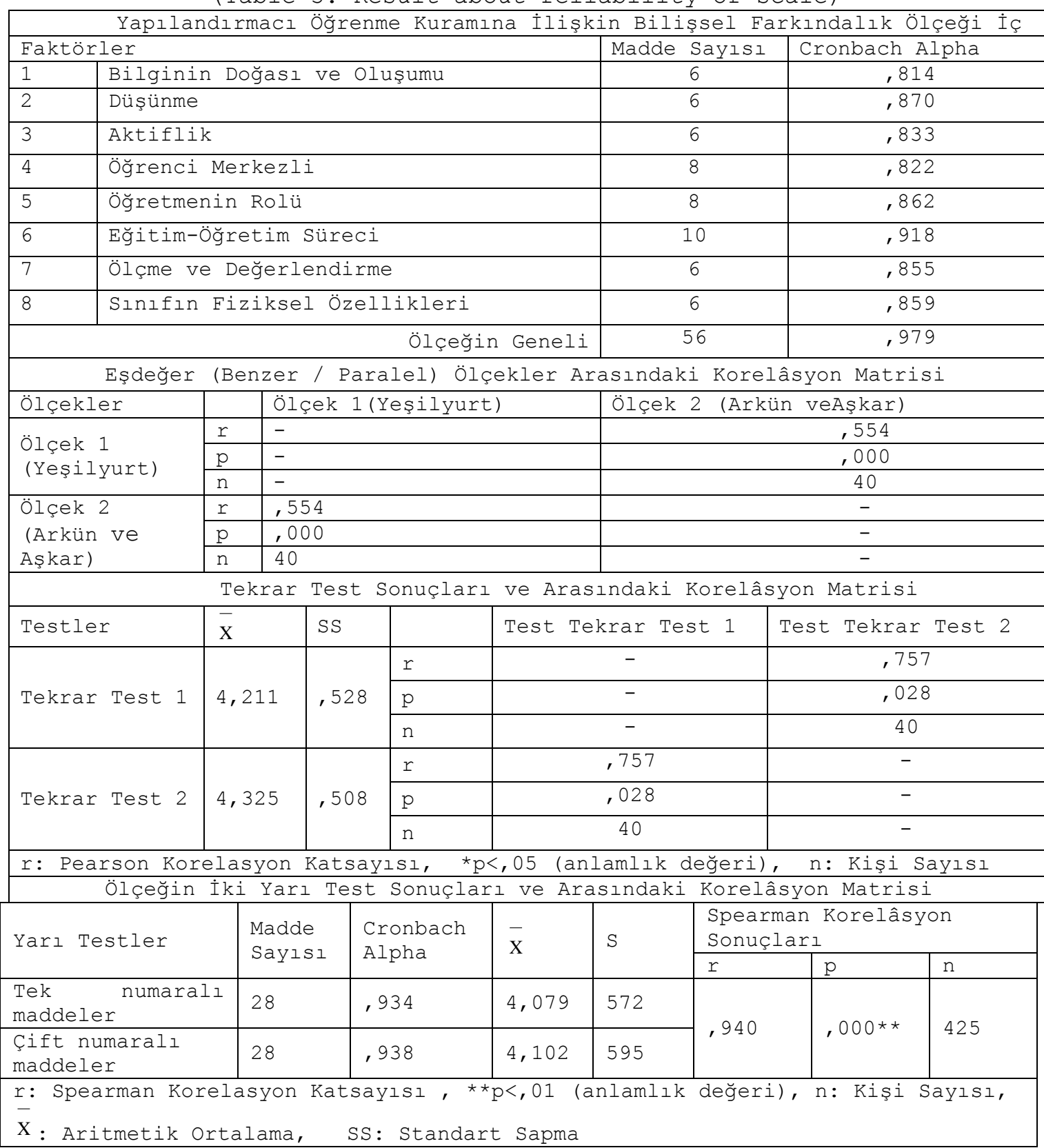

İç tutarlık katsayısı Cronbach Alpha'nın ölçeğin faktörlerinde ,918 ile ,814 arasında değiştiği, ölçeğin genelinde ise bu değerin ,979 olduğu tespit edilmiştir (revize edilen ölçekte yer alan faktörlerin Cronbach Alpha değerleri ,878 ile, 574 arasında olup, bu değer ölçeğin genelinde ise, 940'tır). Ortaya çıkan bu değerler, ölçeğin güvenirlik düzeyi için kabul edilebilir değerler olarak 
yorumlanabilir. Tablo $3^{\prime}$ ten de görüldüğü gibi eşdeğer iki ölçek (ölçek 1: Yeşilyurt; ölçek 2: Arkün veAşkar) arasında ( $r=, 554, p<, 05)$ pozitif yönlü, orta düzeyde ve anlamlı bir ilişki bulunmaktadır. Elde edilen bulgu, her iki ölçeğin de ölçülmek istenilen konu veya özellikleri ölçmede kullanılabileceğini göstermektedir. Öte yandan tekrar test analizlerine bakıldığında, katılımcıların hem tekrar test $1(\bar{X}=4,211)$, hem de tekrar test 2'ye yönelik olarak ( $\mathrm{X}=4,325)$ "tamamen farkındayım" düzeyinde görüş ileri sürdükleri, başka bir ifadeyle farklı zamanlarda uygulanan her iki teste de benzer yanıt verdikleri görülmektedir. Ayrıca iki test arasında ( $r=, 757, p<, 05)$ pozitif yönlü, yüksek düzeyde ve anlamlı bir ilişki bulunmaktadır. Tekrar test analizi sonucunda aritmetik ortalamaların birbirine yakın ve korelasyon değerinin de yüksek olması, testlerin zamana bağlı olarak kararlı ölçümler verdiğini göstermektedir. Ayrıca Tablo 3'te görüldüğü gibi, iki yarı test arasındaki spearman korelasyon değerinin, 940 ( $<<, 01)$ olarak tespit edilmesi, testler arasında mükemmele yakın, pozitif yönde ve anlamlı bir ilişki olduğunu göstermekte ve testlerin birbirleriyle olan yüksek derecedeki tutarlılığını ortaya koymaktadır. Bunların yanı sıra Cronbach Alpha değerinin tek numaralı ölçek maddelerinde, 934 ve çift numaralı ölçek maddelerinde ise, 938 olarak çıkması(revize edilen ölçekte ise Cronbach Alpha tek numaralı maddelerde, 886 ve çift numaralı maddelerde ise, 883'tür), iki grup arasındaki korelasyon değeriyle olan tutarlığını ortaya koymaktadır. Geçerlik analizleri sonucunda olduğu gibi, güvenirlik analizleri sonucunda da elde edilen bu değerler, psikometrik özellikler bakımından ölçeğin kullanılabilir nitelikte olduğunu göstermektedir.

\section{SONUÇ (CONCLUSION)}

Bu çalışmada, makalenin yazarı tarafından geliştirilen, 'yapılandırmacı öğrenme konusunda öğretmen adaylarının yeterliği ölçeği: geçerlik ve güvenirlik çalışması'nın yeniden gözden geçirilerek elde edildiği 'yapılandırmacı öğrenme kuramına ilişkin bilişsel farkındalık ölçeğinin geçerlik ve güvenirliğini test etmek amaçlanmış ve ölçeğin psikometrik özellikleri incelenmiştir. Elde edilen bulgulardan ölçme aracındaki maddelerin ve çalışma grubunun faktör analizi için uygun ve yeterli olduğu tespit edilmiştir. Yine ölçme aracındaki maddeler varyansın 56,907'sini açıklamaktadır. Yapılandırmacı öğrenme kuramına ilişkin bilişsel farkındalık ölçeği için öncelikle açımlayıcı faktör analizi ile sekiz faktörlü bir yapı elde edilmiş ve maddelerin faktör yük değerleri, 852 ile, 457 arasında tespit edilmiştir.

Açımlayıcı faktör analizi ile elde edilen yapı, doğrulayıcı faktör analizi ile model uyumu test edilmiştir. Açımlayıcı faktör analizinden elde edilen sonuçlara paralel olarak, doğrulayıcı faktör analizi sonucunda da 56 madde ve sekiz faktörden oluşan bir model elde edilmiş, modelin kuramsal ve istatistiksel olarak uygun olduğu bulunmuştur. Ayrıca bu sonuçlar, ölçeğin yapı geçerliğinin olduğuna ilişkin bir kanıttır. Güvenirlik çalışmaları kapsamında yapılan iç tutarlık katsayıları, tekrar test, eşdeğer form ve testi yarılama sonucu elde edilen korelasyon değerlerinin de ölçeğin güvenilir olarak kullanılabileceğini göstermektedir.

Bu ölçek, öğretmen adaylarının ve öğretmenlerin yapılandırmacı öğrenme kuramına ilişkin bilişsel farkındalık düzeyini ortaya koymak amacıyla toplam 56 madde ve sekiz faktörden oluşmaktadır. Ölçme aracındaki birinci faktörün adı altı maddeden oluşan "bilginin doğası ve oluşumu"dur. Bu faktör yapılandırmacı öğrenme kuramına göre bilginin doğasını ve nasıl oluştuğunu konu edinmektedir. Ölçeğin 


\begin{abstract}
ikinci faktörü olan "düşünme" ile üçüncü faktörü olan "aktiflik" de altışar maddeden oluşmaktadır. Bu faktörler yapılandırmacı öğrenme kuramına göre düşünme ile öğrenci aktifliğine vurgu yapmaktadır. Dördüncü faktör olan "öğrenci merkezli" faktör ise sekiz maddeden meydana gelmekte ve yapılandırmacı öğrenme kuramı açısından öğrenci merkezli bir eğitim sürecinin özelliklerini özetlemektedir. Sekiz maddeden oluşan beşinci faktörün adı ise "öğretmen rolü"dür. Bu faktör yapılandırmacı öğrenme kuramı açısından bir öğretmenin görev ve sorumluklarına dikkat çekmektedir. Yapılandırmacı öğrenme kuramına göre eğitim-öğretim sürecinin nasıl olması gerektiğine ilişkin olarak ölçekte yer alan faktörün adı "eğitim-öğretim süreci"dir ve madde sayısı ondur. Ölçeğin yedinci faktörünü altı maddelik "ölçme ve değerlendirme" oluşturmaktadır. Bu faktör, yapılandırmacı öğrenme kuramına göre öğrenci başarısının nasıl ölçülüp değerlendirilmesi gerektiği noktasında fikir vermektedir. Ölçeğin son faktörünün adı ise "sınıfın fiziksel özellikleri"dir. Yapılandırmacı öğrenme kuramına göre eğitim-öğretim yapılması için bir sınıfın fiziksel özelliklerinin nasıl olması gerektiğine işaret eden bu faktör altı maddeden oluşmaktadır.

Sonuç olarak, 'yapılandırmacı öğrenme konusunda öğretmen adaylarının yeterliği ölçeği: geçerlik ve güvenirlik çalışması'nın gözden geçirilerek yeniden yapılandırılmış ve geliştirilmiş şekli olan 'yapılandırmacı öğrenme kuramına ilişkin bilişsel farkındalık ölçeği'nin geçerli ve güvenilir bir ölçme aracı olduğu tespit edilmiştir. Öte yandan, elde edilen bulgular doğrultusunda, bu çalışma kapsamında geliştirilen ölçme aracının, ilgili alanyazındaki önemli bir eksikliği gidereceği, bundan sonraki çalışmalarda kullanılabilecek bir ölçme aracı olma özelliği taşıdığı belirtilebilir. Ayrıca geliştirilen bu ölçme aracının, öğretmen adaylarının ve öğretmenlerin yapılandırmacı öğrenme kuramına ilişkin bilişsel farkındalık düzeyinin belirlenmesinde kullanılabilecek geçerli ve güvenilir bir veri toplama aracı olduğu söylenebilir.
\end{abstract}

\title{
NOT (NOTE)
}

Bu çalışma, yazar tarafından geliştirilen ve Uluslararası Avrasya Sosyal Bilimler Dergisi'nde yayımlanan 'Yapılandırmacı Öğrenme Konusunda Öğretmen Adaylarının Yeterliği Ölçeği: Geçerlik ve Güvenirlik Çalışması'nın gözden geçirilerek yeniden yapılandırılmış ve geliştirilmiş şeklidir.

\section{TEŞEKKÜR (THANKS)}

Bu çalışmamda uzman olarak görüşlerine başvurulan ve bu konuda destek veren kıymetli hocalarım; Sayın Prof.Dr. Vehbi ÇELIK (Mevlana Ünv.), Sayın Prof.Dr. Mehmet TAŞPINAR (Gazi Ünv.), Sayın Prof.Dr. Seval FER (Trakya Ünv.), Sayın Doç.Dr. Çetin SEMERCì (Bartın Ünv.), Sayın Doç.Dr. Ahmet KARA (Adıyaman Ünv.), Sayın Yrd.Doç.Dr. Bayram ÖzER (Mustafa Kemal Ünv.), Sayın Yrd.Doç.Dr. Ertuğrul USTA (Mevlana Ünv.), Sayın Yrd.Doç.Dr. Cihad DEMİRLİ (İstanbul Ticaret Ünv.), Sayın Yrd.Doç.Dr. Selim EMİRoĞLU (Mevlana Ünv.), Sayın Yrd.Doç.Dr. Muhammed TURHAN (Fırat Ünv.), Sayın Yrd.Doç.Dr. Erkan IŞIK (Mevlana Ünv.), Sayın Arş.Gör. Bülent Ahmet TURAN (Mevlana Ünv.) ve Sayın Arş.Gör. Muhammed Emre KILIÇ'a içtenlikle teşekkürlerimi sunuyorum. Ayrıca bu çalışmada verileri elde ettiğim ve çalışmama gönüllü olarak katılan katılımcı grupların tamamına da çok teşekkür ederim. 


\section{KAYNAKÇA (REFERENCES)}

1. Açıkgöz, K.Ü., (2007). Aktif öğrenme, İzmir, Biliş Özel Eğitim Yayınları.

2. Arkün, S. ve Aşkar, P., (2010). Yapılandırmacı öğrenme ortamlarını değerlendirme ölçeğinin geliştirilmesi, Hacettepe Üniversitesi Eğitim Fakültesi Dergisi, (39), 32-43.

3. Arslan, M., (2007). Eğitimde yapılandırmacı yaklaşımlar, Ankara Üniversitesi Eğitim Bilimleri Fakültesi Dergisi, $40(1), 41-61$.

4. Aşkar, P. ve Dönmez, 0., (2004). Eğitim yazılımı geliştirme özyeterlik algısı ölçeği, Eğitim Bilimleri ve Uygulama, 3(6), 259268 .

5. Aydın, H., (2006). Postmodernizmin eğitimdeki uzantısı: Felsefi yapılandırmacılık, http://turkoloji.cu.edu.tr/GENEL/hasan_aydin_ egitim_yapilandirmacilik.pdf, Erişim Tarihi: 20 şubat $200 \overline{8}$.

6. Aydın, H., (2007). Felsefi temelleri ışığında yapılandırmacılık, Ankara, Nobel Yayınları.

7. Bağcı, N., (2003). Öğretim sürecinde öğrenciye ve öğrenim amacına yönelik yeni yaklaşımlar, Milli Eğitim Dergisi, http://yayim.meb.gov.tr/dergiler/159/bagci.htm, Erişim Tarihi: $10 \mathrm{Nisan} 2007$.

8. Balcı, A., (2011). Sosyal bilimlerde araştırma yöntem, teknik ve ilkeleri, Ankara, Pegem A Yayıncılık.

9. Bay, E., Kaya, H.і். ve Gündoğdu, K., (2010). Demokratik yapılandırmacı öğrenme ortamı ölçeği geliştirilmesi, e-Journal of New World Sciences Academy, 5(2), 646-664.

10. Bayram, N., (2010). Yapısal eşitlik modellemesine giris,, AMOS uygulamaları, Bursa, Ezgi Yayınevi.

11. Brooks, J.G. and Brooks, M.G., (1999). In search of understanding: The case for constructivist classrooms, Virginia, Association for Supervision and Curriculum Development.

12. Büyüköztürk, Ş., (2007). Sosyal bilimler için veri analizi elkitabı, Ankara, Pegem A Yayıncılık.

13. Büyüköztürk, Ş., Çakmak, E.K., Akgün, Ö.E., Karadeniz, Ş. ve Demirel, F., (2010). Bilimsel araştırma yöntemleri, Ankara, Pegem Akademi.

14. Büyüköztürk, Ş., Çokluk, Ö. ve Köklü, N., (2012). Sosyal bilimler için istatistik, Ankara, Pegem Akademi.

15. Byrne, B.M., (2001). Structural equation modeling with AMOS, Mahwah, N.J. Lawrence Erlbaum Associates.

16. Can, T., (2004). Yabancı dil olarak İngilizce öğretmenlerinin yetiştirilmesinde kuram ve uygulama boyutuyla oluşturmacı yaklaşım, Yayımlanmamış Yüksek Lisans Tezi, İstanbul Üniversitesi Sosyal Bilimler Enstitüsü.

17. Demir, Ö. ve Doğanay, A., (2009). Bilişsel farkındalık becerilerinin geliştirilmesinde bilişsel koçluk yaklaşımı, Kuram ve Uygulamada Eğitim Yönetimi, 15(60), 601-623.

18. Demirel, Ö., (2012). Kuramdan uygulamaya eğitimde program geliştirme, Ankara, Pegem A Yayıncılık.

19. Duman, B. ve İkiel, C., (2002). Yapıcı öğrenme kuramına göre sosyal bilimler öğretimi, Frrat Üniversitesi sosyal Bilimler Dergisi, $12(2), 245-262$.

20. Duman, B., (2004). Öğrenme-öğretmen kuramları ve süreç temelli öğretim, Ankara, Anı Yayıncılık.

21. Durmuş, S., (2001). Matematik eğitiminde oluşturmacı yaklaşımlar, Kuram ve Uygulamada Eğitim Bilimleri, 1(1), 89-107.

22. Ellez, A.M., (2009). Bilimsel araştırma yöntemleri, A. Tanrıöğen (Ed.), Ölçme araçlarında bulunması gereken özellikler (ss. 167190), Ankara, Anı Yayıncılık. 
23. Erdem, E. ve Demirel, Ö., (2002). Program geliştirmede yapılandırmacılık yaklaşımı, Hacettepe Üniversitesi Eğitim Fakültesi Dergisi, (23), 81-87.

24. Ersoy, A., (2005). İlköğretim bilgisayar dersindeki sınıf yerleşim düzeni ve öğretmen rolünün yapılandırmacı öğrenmeye göre değerlendirilmesi, The Turkish Online Journal of Educational Technology, 4(4), 170-181.

25. Evrekli, E., İnel, D., Balım, A.G. ve Kesercioğlu, T., (2009). Fen öğretmen adaylarına yönelik yapılandırmacı yaklaşım tutum ölçeği: Geçerlilik ve güvenirlik çalışması, Türk Fen Eğitimi Dergisi, 6(2), 134-148.

26. Fer, S. ve Cırık, İ., (2006). Öğretmenlerde ve öğrencilerde, yapılandırmacı öğrenme ortamı ölçeğinin geçerlik ve güvenirlik çalışması nedir? Yeditepe Üniversitesi Eğitim Fakültesi Dergisi (EDU7), 2(1), 1-26.

27. Fosnot, C.T. and Perry, R.S., (2005). Constructivism, C. Twomey Fosnot (Ed.) Oluşturmacılık: Psikolojik bir öğrenme teorisi (ss. 9-42, Çev: S. Durmuş), New York and London, Teachers College, Columbia University.

28. Gelen, İ., (2004). Bilişsel farkındalık stratejilerinin Türkçe dersine ilişkin tutum, okuduğunu anlama ve kalıcılığa etkisi, XIII. Ulusal Eğitim Bilimleri Kurultayı, 6-9 Temmuz 2004, İnönü Üniversitesi, Eğitim Fakültesi, Malatya.

29. Gömleksiz, M.N. ve Elaldı, Ş., (2011). Yapılandırmacı yaklaşım bağlamında yabancı dil öğretimi, Turkish Studies, 6(2),443-454.

30. Güneş, F., (2007). Yapılandırmacı yaklaşımla sınıf yönetimi, Ankara, Nobel Yayınları.

31. Gürol, M., (2002). Eğitim teknolojisinde yeni paradigma: Oluşturmacılık, Fırat Üniversitesi Sosyal Bilimler Dergisi, $12(1), 159-183$.

32. Iflazoğlu Saban, A. ve Saban, A. (2008). Sınıf öğretmenliği öğrencilerinin bilişsel farkındalıkları ile güdülerinin bazı sosyo-demografik değişkenlere göre incelenmesi, Ege Eğitim Dergisi, 9(1), 35-58.

33. Jonassen, D.H., Peck K.L., and Wilson, B.G., (1999). Learning with technology: A. constructivisit perspective, New Jersey, Prentice Hall.

34. Joreskog, K.G. and Sorbom, D., (1993). LISREL 8: Structural equation modeling with the SIMPLIS command language, Chicago, Scientific International Software.

35. Kalaycı, Ş., (2006). SPSS uygulamalı çok değişkenli istatistik teknikleri, Ş. Kalaycı (Ed.) Faktör analizi (ss. 321-331), Ankara, Asil Yayın Dağıtım Ltd. Şti.

36. Kayış, A., (2006). SPSS uygulamalı çok değişkenli istatistik teknikleri, Ş. Kalaycı (Ed.) Güvenilirlik analizi (ss. 403-419), Ankara, Asil Yayın Dağıtım Ltd. Şti.

37. Kılıç, E., Karadenğz, Ş. ve Karataş, S., (2003). Internet destekli yapıcı öğrenme ortamları, G.Ü. Gazi Eğitim Fakültesi Dergisi, 23(2), 149-160.

38. Kline, B.R., (2005). Principles and practice of structural equation modeling, New York, The Gullford Press.

39. Kulaksızloğlu, A., Dilmaç, B., Ekşi, H. ve Otrar, M., (2003). Uyum ölçeği-üniversite formu'nun dilsel eşdeğerlik, geçerlik ve güvenirlik çalışması, Eğitim Bilimleri ve Uygulama, 2(3), 49-63.

40. Küçüközer, H., Kırtak Ad, V.N., Ayverdi, L. ve Eğdir, S., (2012). Yapılandırmacı öğrenme ortamları ölçeğinin Türkçe'ye uyarlanması, İlköğretim Online, 11(3), 671-688. 
41. Laçin, Ö., (2008). Yapılandırmacılık (Constructivism), http://www2. aku.edu.tr/ gocak/program20gelpdf/YAPILANDIRMACILIK.pdf,Erişim Tarihi: 2 Ocak 2008.

42. Marlowe, B.A. and Page, M.L., (1998). Creating and sustaining the constructivist classroom, California, Corwin Press, Inc.

43. Mısır, Z.E. ve Çalışkan, N., (2007). Kuramdan uygulamaya yapılandırmacı öğrenme yaklaşımı, E. Karadağ ve T. Korkmaz (Ed.) Yapılandırmacı öğrenmede dikkat edilmesi gereken koşullar (ss. 59-84), Ankara, Kök Yayıncılık.

44. Özden, Y., (2003). Öğrenme ve öğretme, Ankara, Pegem A Yayıncılık.

45. Perkins, D.N., (1999). The many faces of constructivism, Educational Leadership, 57(3), 6-11.

46. Reisinger, Y. and Mavondo, F.T., (2006) Structural equation modeling: Critical issues and new development, Journal of Travel and Tourism Marketing, 21(4), 41-72.

47. Schermelleh-Engel, K. and Moosbrugger, H., (2003). Evaluating the fit of structural equation models: Tests of significance and descriptive goodness-of-fit measures, Methods of Psychological Research Online, 8(2), 23-74.

48. Sert, N., (2008). İlköğretim programlarında oluşturmacılık, Eğitimde Kuram ve Uygulama, 4 (2), 291-316.

49. Sönmez, V., (2011). Eğitim felsefesi, Ankara, Anı Yayıncılık.

50. Şaşan, H. (2002). Yapılandırmacı öğrenme, Yaşadıkça Eğitim, (74$75), 49-52$.

51. Şimşek, N., (2004). Yapılandırmacı öğrenme ve öğretime eleştirel bir yaklaşım, Eğitim Bilimleri ve Uygulama, 3(5), 115-139.

52. Şimşek, Ö.F., (2007). Yapısal eşitlik modellemesine giriş, temel ilkeler ve LISREL uygulamaları, Ankara, Ekinoks Yayınları.

53. Tavşancıl, E., (2006). Tutumların ölçülmesi ve SPSS ile veri analizi, Ankara, Nobel Yayınları.

54. Thomas, M.S. and Barbara L.K., (2005). Constructing learning: Using technology to support teaching for understanding, Learning and Leading with Technology, 32(5), 10-13.

55. Tsai, C.C., (2002). Nested epistemologies: science teachers' beliefs of teaching, learning and science, International Journal of Science Education, 24(8), 771-783.

56. Turgut, M.F. ve Baykul, Y., (1992). Ölçekleme teknikleri, Ankara, ÖSYM yayınları.

57. Von Glasersfeld, E. (2005). Constructivism, C. Twomey Fosnot (Ed.) Giriş: Oluşturmacılığın yansımaları (ss. 3-8, Çev: S. Durmuş), New York and London, Teachers College, Columbia University.

58. Yanpar, T., (2001). İlköğretimde oluşturmacı (constructivist) bir sınıf kültürü yaratma, Yaşadıkça Eğitim, (72), 27-32.

59. Yapıcı, M., (2008). Yapılandırmacılık ve sınıf, http://www. universite-toplum.org/pdf/pdf.php?id=312, Erişim Tarihi: 10 Ocak 2008 .

60. Yaşar, Ş., (1998). Yapısalcı kuram ve öğrenme-öğretme süreci, Anadolu Üniversitesi Eğitim Fakültesi Dergisi, 8(1-2), 68-75.

61. Yeşilyurt, E., (2012). Yapılandırmacı öğrenme konusunda öğretmen adaylarının yeterliği ölçeği: Geçerlik ve güvenirlik çalışması, Uluslararasi Avrasya Sosyal Bilimler Dergisi, 3(7), 29-45.

62. Yolcu, H., (2009). Bilimsel araştırma yöntemleri, A. Tanrıöğen (Ed.), Bilimsel araştırmaya ilişkin temel kavramlar, (ss. 3-28), Ankara, Anı Yayıncılık. 
63. Yurdakul, B., (2007). Eğitimde yeni yönelimler, Ö. Demirel

(Ed.) Yapılandırmacılık (ss. 39-65), Ankara, Pegem A Yayıncılık.

64. Yurdakul, B., (2008). Yapılandırmacı öğrenme yaklaşımının sosyal-bilişsel bağlamda bilgiyi oluşturmaya katkısı, Balıkesir Üniversitesi Sosyal Bilimler Enstitüsü Dergisi, 11(20), 39-67. 